\title{
Penetrasi Jepang Dan Dampaknya Terhadap Batik Pekalongan, 1930-1945
}

\author{
Satrya Paramanandana, Ismail Lutfi, Lutfiah Ayundasari* \\ Universitas Negeri Malang \\ *Corresponding author`s e-mail: Lutfiah.fis@um.ac.id
}

\begin{abstract}
This research discusses the Japanese penetration of the Dutch East Indies in the years 1930-1945. Japan in the 1930s began to dominate the Dutch East Indies economy, especially in terms of exports of fabrics. In addition, in 1942, the Japanese occupation caused a fabric crisis in the Dutch East Indies. This economic and military penetration had an impact on batik in Pekalongan. This study uses a historical method with a cultural history approach. This is because this article focuses on the cultural morphology due to the penetration of the Japanese economy and military. This change was recorded in the Pekalongan batik period 1930-1945. The discussion in this article includes the golden age and the fall of the batik industry in Pekalongan in 1929-1930, the trend of batik styles in Pekalongan by 1930, and the impact of Japanese penetration on Pekalongan batik in 1930-1945. The results showed that the Japanese economic and military penetration of the Dutch East Indies influenced batik in Pekalongan in terms of the availability of fabrics for the batik industry and changes in batik trends and distinctive Japanese color patterns due to market tastes.
\end{abstract}

Keywords: Japanese; penetration; batik; Pekalongan

Abstrak: Penelitian ini membahas mengenai penetrasi Jepang ke Hindia Belanda pada tahun 1930-1945. Jepang pada tahun 1930-an mulai mendominasi perekonomian Hindia Belanda terutama dalam hal ekspor kain. Selain itu pada tahun 1942, pendudukan Jepang menimbulkan krisis kain di Hindia Belanda. Penetrasi yang dilakukan secara ekonomi dan militer ini berdampak pada batik di Pekalongan. Penelitian ini menggunakan metode sejarah dengan pendekatan sejarah kebudayaan. Hal ini karena dalam artikel ini menyoroti morfologi budaya akibat penetrasi ekonomi dan militer Jepang. Perubahan ini terekam dalam batik Pekalongan periode 1930-1945. Pembahasan dalam artikel ini antara lain masa keemasan dan jatuhnya industri batik di Pekalongan pada 1929-1930, tren gaya batik di Pekalongan menjelang 1930, dan dampak penetrasi Jepang terhadap batik Pekalongan tahun 1930-1945. Hasil penelitian menunjukkan bahwa penetrasi ekonomi dan militer Jepang terhadap Hindia Belanda memengaruhi batik di Pekalongan dari segi ketersediaan kain untuk industri batik dan perubahan tren batik serta tata warna khas Jepang akibat selera pasar.

Kata kunci: Jepang; penetrasi; batik; Pekalongan

\section{Pendahuluan}

Jepang pada tahun 1930-an mengalami situasi ekonomi yang berbanding terbalik dengan negara-negara lain di dunia. Ketika dunia mengalami Depresi Ekonomi, Jepang justru sedang dalam fase produktif. Kebijakan deflasioner yang diambil Jepang pada rentang tahun 1927-1931 menyebabkan ongkos produksi barang semakin murah. Ditambah dengan kebijakan devaluasi yen dan penurunan biaya angkutan maskapai pelayaran Jepang menyebabkan Jepang dapat bersaing dengan negara-negara eksportir ke Hindia Belanda (Nawiyanto, 2010; van Der Eng, 2013; Wie, 2013). Faktor-faktor yang telah disebutkan begitu menguntungkan dominasi ekonomi Jepang khususnya di Hindia Belanda pada dekade 1920 hingga 1930an. Hal ini juga ditunjang strata sosial warga Jepang pasca Perang Cina- 
Jepang dan Rusia-Jepang (1904-1905). Orang-orang Jepang di Hindia memiliki posisi setara dengan orang Eropa (Shiraishi \& Shiraishi, 1998). Kondisi ini berbeda dengan golongan Timur Asing lainnya seperti keturunan Tiongkok dan Arab yang memiliki strata sosial di bawahnya. Ketika Jepang mulai menduduki Hindia Belanda pada tahun 1942 terjadi berbagai permasalahan. Salah satu problematika yang muncul akibat peralihan kekuasaan ini adalah kelangkaan bahan-bahan mentah. Oleh karena itu pemerintahan pendudukan membentuk Jūyō Busshi Kōdan atau Perusahaan Komoditas Utama yang berperan dalam distribusi bahanbahan mentah (Post, 2009:221). Hal ini diperparah dengan penimbunan barang utamanya bahan sandang oleh pejabat-pejabat lokal yang menyebabkan kain begitu sulit diperoleh (Lucas, 2020).

Industri batik merupakan salah satu yang terdampak akibat perubahan ekonomi dan militer yang terjadi. Kain katun sebagai bahan baku utama dalam produksi batik mengalami perubahan dalam hal ketersediaan. Hal ini dikarenakan sejak 1830 kain katun secara dominan diimpor dari luar negeri, utamanya India (Istari, 2016; Van Der Eng, 2013). Membanjirnya katun grey atau blacu asal Jepang pada tahun 1930-an menghancurkan dominasi kain katun produksi perusahaan Twente asal Belanda (Furnivall, 2010). Kelangkaan kain katun putih impor pada dekade 1930-an menyebabkan harga kain batik turut melambung (Wirodihardjo, 1954). Hal ini karena jenis kain yang umum digunakan dalam industri batik berasal dari perusahaan katun tersebut, contohnya adalah primissima cap sen merah (Manex N.V. Oldenzal, 1953; Susanto, 1974). Pekalongan merupakan salah satu pusat produsen batik di pesisir utara Jawa yang berkembang pesat (Rouffaer, 1904). Awal perkembangan batik di Pekalongan sendiri terdapat tiga versi yakni berkembang pasca Perang Diponegoro (1825-1830) (Ilyas, 2018; Pratiwi, 2013), dikembangkan oleh pembesar istana Mataram masa Sultan Agung, Kiai Adipati Mandurareja atau Tumenggung Bahureksa pada sekitar tahun 1622-1628 (Ilyas, 2018) dan berkembang dari Pekalongan sendiri yang notabene terletak di pesisir justru mempengaruhi perkembangan batik di Mataram (Haryono, 1990; Ilyas, 2018).

Ketiga versi ini masih dalam perdebatan. Namun apabila mengacu pada Graaf (1986), pasca ekspansi Mataram di masa Sultan Agung (1613-1645) orang-orang di pesisir utara Jawa termasuk para perajinnya dipekerjakan di Mataram maka versi terakhir yang lebih memungkinkan. Pembahasan seputar batik di Pekalongan sebelumnya telah dilakukan. Semisal Nurhayati (2018) yang menjelaskan mengenai industri, pengusaha Indo-Eropa dan motif-motif batik di Pekalongan tahun 1830-1945 Selain itu Pratiwi (2013) mengkaji tentang perkembangan industri batik di Pekalongan rentang tahun 1950-1970. Selain itu kajian dari 
aspek visual batik pagi sore dan 'Jawa Hokokai' juga telah dikaji oleh Purnomo (2018) dan Sutriyanto \& Kristanti (2014). Pembahasan dalam penelitian sebelumnya belum mengkaji mengenai penyebab hadirnya pengaruh Jepang dalam batik Pekalongan secara mendalam. Pendudukan Jepang di Hindia Belanda dan pendirian Jawa Hokokai dianggap sebagai penyebab utama eksistensi batik dengan pengaruh Jepang. Padahal berdasarkan koleksi Weereld Museum Rotterdam terdapat batik bernuansa Jepang yang dibuat pada tahun 1941. Pengaruh penetrasi ekonomi Jepang terhadap industri batik di Pekalongan masih belum muncul dalam penelitian sebelumnya. Selain itu selera pasar batik yang dipengaruhi penetrasi dan pendudukan Jepang juga belum dibahas. Hal ini dikarenakan penelitian sebelumnya cenderung berfokus pada perkembangan industri dan aspek seni batik di Pekalongan itu sendiri.

Tujuan dari artikel ini adalah mengetahui masa keemasan dan jatuhnya industri batik di Pekalongan pada 1920-1930, tren gaya batik di Pekalongan menjelang 1930, dan dampak penetrasi Jepang terhadap batik Pekalongan tahun 1930-1945. Industri batik dan tren gaya batik di Pekalongan sebelum 1930 perlu diketahui sebagai perbandingan terhadap dampak penetrasi Jepang terhadap batik Pekalongan dalam rentang waktu yang telah disebutkan.

\section{Metode}

Metode yang digunakan dalam artikel ini adalah metode sejarah. Menurut Kuntowijoyo (2013) terdapat lima tahap dalam metode ini. Tahapan-tahapan tersebut antara lain pemilihan topik, pengumpulan sumber, kritik sumber, interpretasi, dan penulisan atau historiografi. Pemilihan topik dilakukan berdasarkan kedekatan intelektual penulis yakni dengan tersedianya sumber secara memadai. Sumber primer yang digunakan dalam artikel ini meliputi katalog kain putih produksi perusahaan kain Twente tahun 1954, koran-koran dalam rentang tahun 1929-1936, laporan Residen Pekalongan tahun 1923, laporan tentang industri batik tahun 1930, Indische Verslag tahun 1936 serta foto kain batik dari periode 1930-1945. Selain itu ditunjang dengan sumber sekunder berupa artikel ilmiah, skripsi dan buku-buku yang menunjang informasi mengenai batik Pekalongan. Buku-buku yang menunjang di antaranya adalah buku katalog kain batik koleksi Santosa Doellah, Empu Batik sekaligus pemilik Batik Danar Hadi. Selain itu buku-buku terbitan Balai Penjelidikan Batik (sekarang Balai Kerajinan dan Batik) semisal "Penuntun Batik" oleh Hadisoemarto \& Soetopo (1953) menjadi acuan. Penulis memilih pendekatan sejarah kebudayaan dalam artikel ini. Fokus dalam artikel ini pada morfologi budaya yang muncul akibat penetrasi ekonomimiliter Jepang ke Hindia Belanda. Sejarah kebudayaan sendiri merupakan usaha mencari 
morfologi budaya (Huizinga dalam Kuntowijoyo (2013)). Gejala perubahan budaya yang muncul akibat penetrasi ekonomi-militer Jepang pada periode 1930-1945 menjadi fokus artikel ini.

\section{Hasil Dan Pembahasan}

\section{Masa Keemasan dan Jatuhnya Industri Batik di Pekalongan, 1920-1930}

Dekade 1920-an merupakan periode keemasan industri batik di Pekalongan (Elliot, 2004). Pekan raya tahunan pertama di Pekalongan diadakan pada tahun 1923 merupakan indikator betapa meriahnya minat akan kerajinan batik. Saat itu Johann Ernst Jasper (18741945) menjabat sebagai Residen Pekalongan. Tercatat ada 113 pengusaha batik ternama yang berpartisipasi dalam pekan raya ini, salah satunya adalah Eliza van Zuylen (Jasper, 1923). Bukti lainnya dapat dijumpai dalam Memorie van Overgave van den Resident van Pekalongan 10 Juni 1926 yang menyebutkan bahwa batik menjadi produk massal ketika J.E. Jasper menjabat. Bahkan pada tahun 1925 ekspor batik Pekalongan telah mencapai Padang, Belawan-Deli, Singapura dan Penang (Angelino, 1930). Usaha batik di Pekalongan hingga tahun 1927 tercatat mencapai 1037 usaha yang tersebar di 3 distrik. Distrik tersebut antara lain Distrik di Pekalongan dibagi menjadi tiga yakni Distrik Kota, Distrik Kedoengwuni, dan Distrik Wiradesa. Pabrik yang ada di District Kota antara lain di Onderdistrict Boewaran, Tirto, Pontjol dan Kota. Sementara di District Kedoengwoeni ada di Onderdistrict Kedoengwoeni, dan Wonopringgo. Terakhir ada di District Wiradesa antara lain di Onderdistrict Wiradesa, Remboen, dan Sragi (Angelino, 1930).

Pola industri batik yang berkembang di Pekalongan terdapat dua tipe. Salah satu pola industri batik yang diadaptasi di Pekalongan adalah desa batik. Sistem desa batik umumnya diterapkan oleh kalangan bumiputera. Batik hasil produksi desa-desa batik ini dijual melalui bakoel (perantara penjualan batik (Angelino, 1930)) yang mendapatkan komisi 0,5 hingga $1 \%$ dari pembatik (Elliot, 2004). Sistem desa batik memiliki keunggulan tersendiri yakni secara kuantitas. Batik kasar secara kuantitas diproduksi lebih banyak daripada batik halus karena adanya kebutuhan batik murah utamanya di tengah masa malaise dekade 1930an. Hal ini yang menurut Angelino (1930) menjadikan perusahaan-perusahaan batik Arab dan Tionghoa tidak dapat menandingi desa-desa tersebut. Tipe pola industri selanjutnya adalah perusahaan batik. Sistem ini digunakan oleh semua etnis di Pekalongan baik bumiputera sendiri, Indo-Belanda, Tionghoa dan Arab. Usaha batik oleh ketiga kelompok terakhir telah berjalan sejak tahun 1850 (Elliot, 2004). Orang-orang Indo-Belanda mengandalkan sistem seleksi dan persekot (pembayaran dengan uang muka (Kramers \& van Wely, 1960)) (Veldhuisen, 2007). Sementara orang-orang Tionghoa memiliki sistem jejaring 
produksi batik. Veldhuisen (2007) menyebutkan bahwa terdapat pengusaha Tionghoa yang bergerak di perusahaan pewarnaan maupun penyedia bahan-bahan batik, di antaranya adalah Hoo Ie Poen dan Oey Hong Hie (Hwat, 1934) Hal ini berfungsi untuk menopang industri batik Tionghoa itu sendiri. Mengenai usaha batik dari kalangan Arab belum begitu banyak informasi hingga artikel ini dibuat.

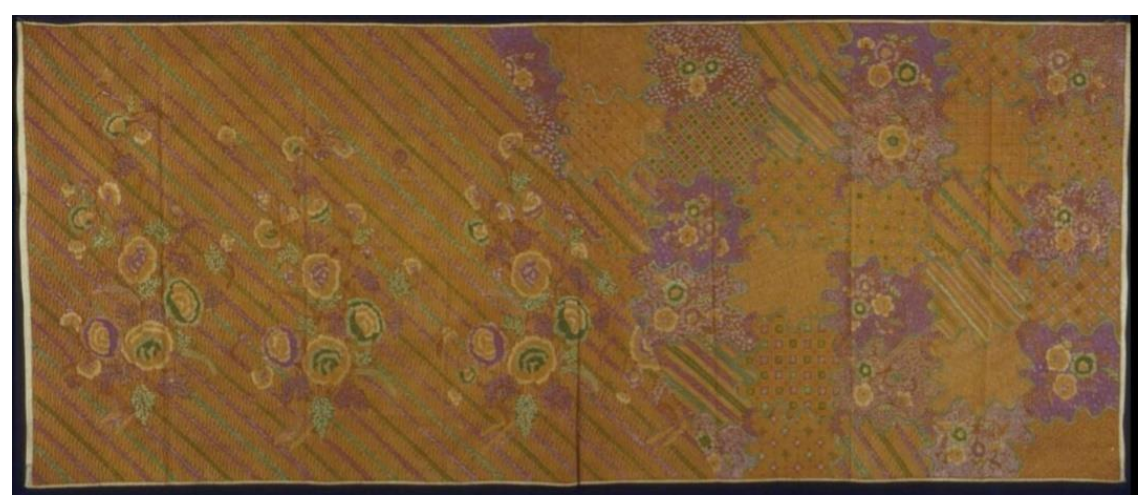

\section{Gambar 1. Batik Jawa Hokokai oleh A. Alaidrus tahun 1945. Kain berukuran $258 \times 106,5 \mathrm{~cm}$ (Wereld Museum Rotterdam).}

Diketahui bahwa jejaring dalam industri batik di Pekalongan berdasarkan kesamaan etnis dan keluarga. Jaringan keluarga pengusaha batik di Pekalongan memiliki wilayah klaster tersendiri. Kalangan Indo-Eropa berada di Bugisan dan Heerenstraat (Veldhuisen, 2007), sementara kalangan Tionghoa di Pecinan dan Kedungwuni (Elliot, 2004; Gondowinoto \& Merta, 2019). Berdasarkan Widjaja (2020), sebelum Oey Soe Tjoen membangun perusahaan batik tulis, ayah dan kakeknya Oey Kie Boen dan Oey Kheng Tik telah bergerak di industri batik cap. Contoh lainnya adalah dalam keluarga van Zuylen, Christina merintis usaha batik kemudian Eliza adiknya membuka usaha batik sendiri (Veldhuisen, 2007). Sementara juga ditemukan batik produksi anggota marga al-Aydrus yang membuat batik. Diketahui bahwa marga ini juga merupakan marga Hadrami yang terkemuka di lingkungan Keraton Yogyakarta (Fatiyah, 2016).

Masa keemasan batik Pekalongan seketika merosot memasuki masa malaise pada 1929 akhir. Produksi batik di desa-desa Pekalongan mengalami mati suri atau sek pedjah. Akibatnya, banyak terjadi alih profesi di kalangan pengusaha maupun pekerja batik. Pengusaha-pengusaha batik sebagian beralih ke usaha warung makanan. Pembatik, tukang cap dan buruh-buruh batik bertahan hidup baik dengan menangkap ikan bahkan sampai menjual hartanya untuk pindah ke luar Jawa (Angelino, 1930; Hayati, 2015). Perubahan mata pencaharian ini menyebabkan keterbatasan tenaga kerja yang bergerak dalam industri batik. 
Krisis penting lainnya yang dialami industri batik pada masa malaise adalah terbatasnya ketersediaan kain. Gelombang impor kain dari Jepang pada tahun 1930-an turut berperan dalam jatuhnya industri batik di Pekalongan. Kain yang berkualitas rendah justru disuplai dari Jepang. Kain grey (blacu) pada tahun 1934 sebagian besar diimpor dari Jepang ("Japan En Batik," 1934). Bahkan pada triwulan kedua tahun 1935, pesanan untuk kain grey mencapai angka 100 juta meter (Indisch Verslag, 1936). Hal ini disebabkan oleh katun putih yang diimpor dari Belanda dan Inggris menjadi terbatas. Selain itu, industri pemintalan kain lokal juga turut terdampak (Nawiyanto, 2010; van Der Eng, 2013; Wie, 2013). Usaha yang dilakukan baik dari kalangan pengusaha batik maupun pemerintah Hindia Belanda akan dibahas di pembahasan selanjutnya.

\section{Tren Batik di Pekalongan Menjelang 1930}

Perkembangan batik di Pekalongan tidak dapat terlepas dari tren mode yang ada. Pada tahun 1900, batik produksi asal pesisir utara Jawa utamanya dari Pekalongan mendominasi di Bandung sebagai pusat mode batik. Hal ini titik balik mode batik yang awalnya berkiblat ke Vorstenlanden atau wilayah kerajaan (Veldhuisen, 2007). Faktor ini turut mempengaruhi motif maupun tata warna yang populer diproduksi di Pekalongan.

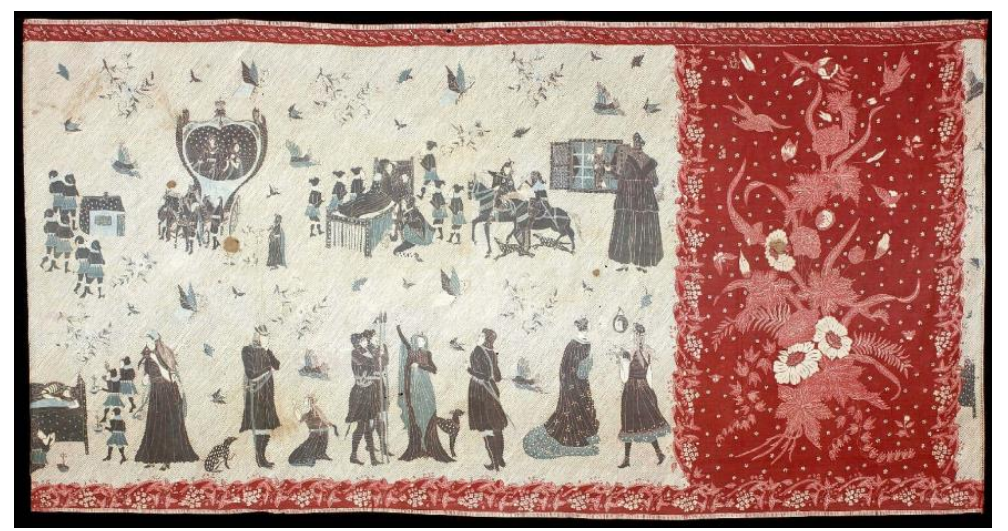

Gambar 2. Batik dongeng Sneeuwwitje (Putri Salju atau Snow White) sekitar tahun 1870-1900. Kain berukuran $204 \times 105 \mathrm{~cm}$ (Wereld Museum Rotterdam)

Sebelum tahun 1900, batik-batik Pekalongan maupun pesisir utara masih mengacu ke motif Vorstenlanden. Pewarnaan yang digunakan juga masih belum begitu variatif. Semisal pada batik produksi pengusaha Indo-Belanda dan Tionghoa masih menggunakan tata warna bang biron dan kelengan. Tata warna ini tercatat dalam History of Java oleh Raffles (1830). Raffles menyebutkan adanya batik latur (latar atau warna dasar) puti (putih), ireng (hitam atau kelengan) dan bang (merah) (Raffles, 1830:188). Memang sudah ada pengembangan motif seperti motif dongeng-dongeng Eropa (lihat foto 1). Bahkan dapat dijumpai motif 
Perang Lombok yang kini lebih populer disebut sebagai motif kumpeni (Veldhuisen, 2007). Memasuki awal tahun 1900-an mulai muncul gaya batik tiga negeri. Gaya batik ini dipopulerkan oleh keluarga Tjoa dari Surakarta utamanya setelah tahun 1910 (Rizali, 2018:104). Perpaduan yang dapat ditemukan dalam batik tiga negeri adalah ciri khas batik Pekalongan, Surakarta dan Lasem. Umumnya gaya batik ini dapat dilihat dari aspek tata warnanya yakni coklat sogan dari Surakarta, biru dari Pekalongan dan merah dari Lasem (Malagina, 2018). Proses pencantingan dan pewarnaan awal (mbironi) dilakukan di wilayah pesisir. Sementara proses pencantingan dan pewarnaan akhir (nyoga) dilakukan di wilayah pedalaman. Proses panjang dan lintas wilayah yang menyebabkan batik tiga negeri menurut Elliot (2004) menjadi mahal dan dianggap sempurna.

Fenomena pewarnaan batik lintas wilayah ini dalam proses pembatikan batik tiga negeri merupakan usaha untuk mendapatkan batik dengan kualitas terbaik. Pewarnaan yang saat itu mengandalkan pewarna alami menghasilkan warna batik yang khas di tiap daerah. Semisal warna merah dari tanaman mengkudu yang berasal dari Lasem. Selain itu warna biru dari tanaman indigo diperoleh dari Pekalongan dan Sukoharjo. Sementara warna coklat dari kayu soga asal Surakarta (Malagina, 2018). Pekalongan sendiri menjadi penting sebagai jalur pembuatan batik tiga negeri, walaupun cenderung terbatas sebagai penyedia pewarna indigo bagi Surakarta dan pencelupan warna dari jalur Lasem. Pewarnaan alami lintas daerah tidak selalu dilakukan. Pekalongan memiliki resep pewarnaan alami tersendiri. Jasper \& Pirngadie (1916) mencatat bahwa untuk membuat warna merah yakni campuran akar mengkudu Eropa (Morinda tinctoria), mengkudu Jawa (Morinda citrifolia), dan daun jirek atau menteng (Baccaurea javanica). Selanjutnya untuk warna kuning (soga) menggunakan campuran kayu tegeran, gula batu, dan jeruk nipis. Selain itu juga terdapat warna wungu (campuran resep warna biru dari indigo dan merah) dan violet (campuran resep warna biru dan soga). Penggunaan tanaman-tanaman ini juga sudah tercatat sejak 1830 dalam History of Java oleh Raffles.

Masuknya pewarna sintetis dari Jerman ke Hindia Belanda pada tahun 1900 juga menambah kreasi warna batik di Pekalongan (Veldhuisen, 2007). Alternatif bahan untuk warna dasar semisal kuning yang sebelumnya alami digantikan dengan Auramine dan pewarna sintetis lainnya (Hadisoemarto \& Soetopo, 1953; Jasper \& Pirngadie, 1916). Para pengusaha batik Tionghoa banyak bereksperimen dengan warna-warna yang sulit diproduksi pewarna alami. Hal ini menyebabkan para pengusaha batik yang mengandalkan pewarna alami ikut beradaptasi karena ongkos produksi yang lebih murah. Namun di sisi lain bagi mereka yang tetap bertahan dengan pewarna alami mengalami penurunan jumlah pesanan (Veldhuisen, 2007). Hal ini disebabkan oleh harga batik dengan pewarna sintetis 
lebih terjangkau. Perlu menjadi catatan bahwa selama hingga akhir Perang Dunia I juga terjadi kelangkaan bahan kain katun yang otomatis sedikit banyak berpengaruh pada pasar batik (Elliot, 2004; Valen, 2016). Hadirnya pewarna sintetis membantu para pengusaha dan perajin batik untuk tetap dapat memproduksi batik. Selain ongkos produksi yang lebih murah, warna juga digunakan lebih bervariasi. Terdapat beberapa jenis pewarna sintetis yang masuk di Hindia Belanda, di antaranya adalah Auramine, Napthol (ditemukan tahun 1912), dan Indigosol (ditemukan tahun 1921) (Chattopadhyay, 2011; Hadisoemarto \& Soetopo, 1953).

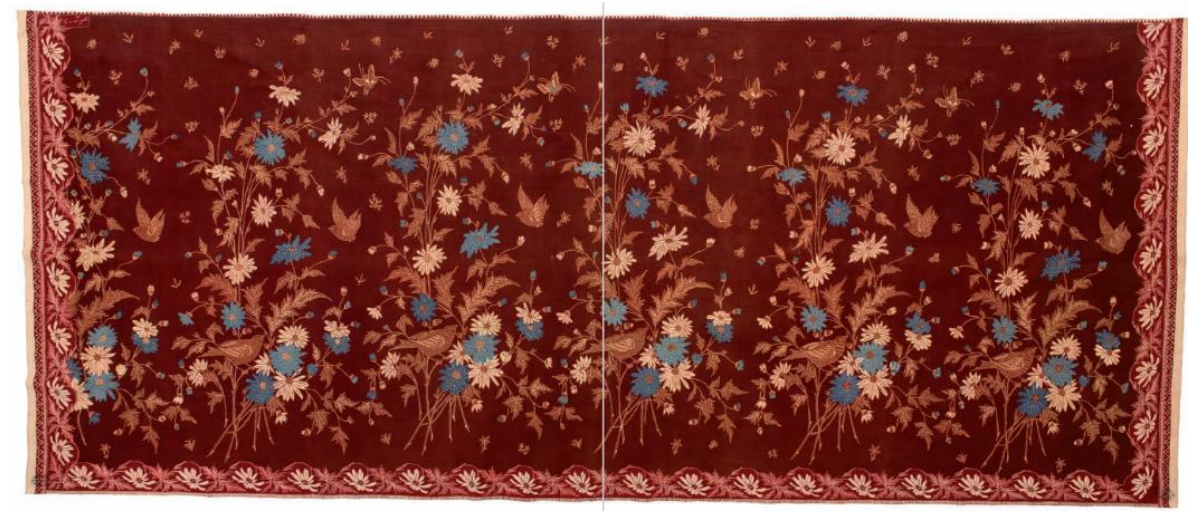

\section{Gambar 3. Batik bukétan Eliza van Zuylen, asal Pekalongan tahun 1930 Kain berukuran $205 \times 106 \mathrm{~cm}$. (Smend, 2015)}

Eliza van Zuylen, seorang pengusaha batik Indo-Belanda mempopulerkan motif bukétan (lihat foto 2) pada tahun 1900 (Elliot, 2004; Veldhuisen, 2007). Motif ini merupakan pengembangan dari ornamen-ornamen bunga yang populer digunakan dalam batik-batik produksi pengusaha Indo-Belanda. Semisal nyonya J. Fishfer yang dipadukan dengan motif bangau dan J. Jans dengan motif bunga iris dan daun teratai, yang mana keduanya mengadaptasi gaya Art Deco yang menjadi tren dunia pada awal 1900-an (Elliot, 2004; Veldhuisen, 2007). Pewarnaan Lies juga bervariasi, mengikuti pasar peranakan Tionghoa. Motif bukétan yang begitu populer rupanya menimbulkan permasalahan hak cipta. Bermunculan tiruan dari batik-batik keluaran Eliza van Zuylen. Hal ini menyebabkan Lies, sapaan Eliza van Zuylen lebih berhati-hati dalam memproduksi batik. Ditetapkannya Auteursrechten 1914 menyebabkan Lies untuk memberi stempel di setiap batik yang diproduksi. Lies terinspirasi dari pengusah-pengusaha batik Tionghoa yang terlebih dahulu menerakan stempel pada batik (Veldhuisen, 2007). Kepopuleran motif bukétan juga menjadi inspirasi dari Oey Soe Tjoen (Mulyawan, 2017; Widjaja, 2020). Berbeda dengan Lies, Oey Soe 
Tjoen bersama istrinya, Kwee Nettie lebih berani bereksperimen dalam hal warna. Selain itu, Oey Soe Tjoen membidik pasar peranakan Tionghoa. Oleh karenanya, batik keluaran Oey Soe Tjoen dengan cepat menjadi populer (Veldhuisen, 2007).

\section{Dampak Penetrasi Jepang terhadap Batik Pekalongan Tahun 1930-1945}

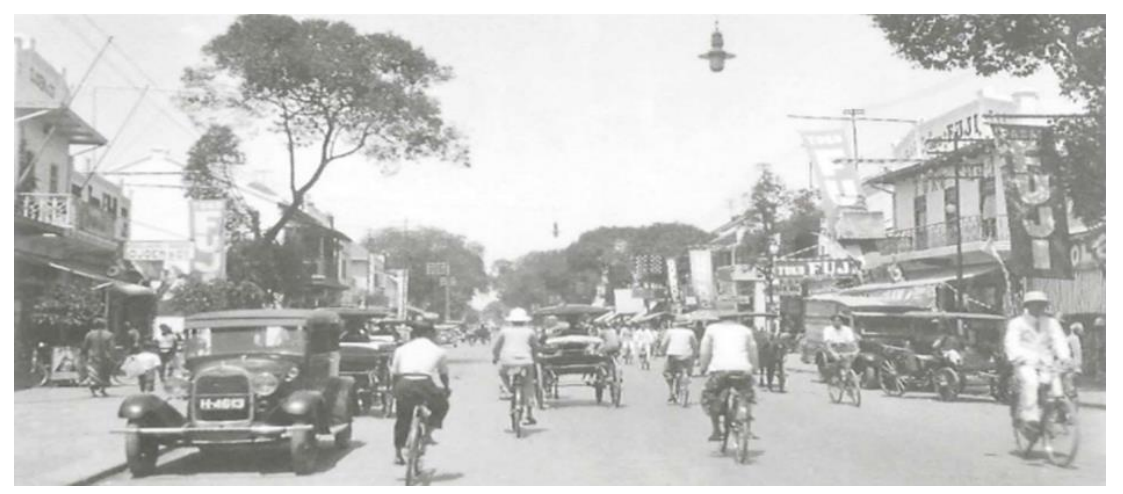

Foto 4. Toko Fuji di Malioboro, Yogyakarta tahun 1935. Foto oleh J. Anten (Bruggen et al. (1998))

Orang-orang Jepang di Hindia Belanda sebagian besar bergerak di bidang perdagangan. Pada tahun 1920 terhitung 71,6\% orang Jepang bekerja di sektor ini (Murayama, 1998). Salah satu komoditas yang diperdagangkan adalah batik. Jaringan toko Fuji Yoko adalah salah satunya. Jaringan ini didirikan oleh Sawabe Masao di Yogyakarta pada tahun 1920 (Murayama, 1998; Nawiyanto, 2010; Post, 2009; Veldhuisen, 2007). Sawabe Masao dijuluki sebagai raja batik Yogyakarta, karena turut berperan dalam mendorong perkembangan industri batik pada dekade 1930-an (Post, 2009).

Jaringan dagang Fuji Yoko semakin berkembang pasca Sawabe Masao memiliki menantu. Kaneko Kenji, menantu Sawabe Masao semula bekerja dengan Masao di Toko Fuji. Selanjutnya ia memutuskan untuk membuka tokonya sendiri, Toko Kaneko di Kutoarjo (Post, 2009). Nawiyanto (2010) menyebutkan bahwa jejaring ini berkembang pesat di kota-kota Jawa bagian tengah. Pekalongan yang notabene wilayah produsen batik memungkinkan untuk mendapat pengaruh dalam jaringan perdagangan batik ini.

Tabel 1. Daftar harga kain yang mendapatkan pengurangan harga per blok.

\begin{tabular}{|c|c|c|c|}
\hline Merek dan Jenis & $\begin{array}{c}\text { Ukuran } \\
\text { (dalam yard) }\end{array}$ & $\begin{array}{c}\text { Pemotongan } \\
\text { Harga per piece }\end{array}$ & Negara Asal \\
\hline $\begin{array}{l}\text { Cent Merah Hard Finish } \\
\text { (Primissima) }\end{array}$ & $42 / 17$ & $f 0,22 \frac{1}{2}$ & Belanda \\
\hline $\begin{array}{l}\text { Djangkrik II Soft Finish } \\
\text { (Primissima) }\end{array}$ & $42 / 17$ & $f 0,22 \frac{1}{2}$ & Belanda \\
\hline $\begin{array}{l}\text { Blue Bird } \\
\text { (Diduga Primissima) }\end{array}$ & $42 / 171 / 2$ & $f 0,171 / 2$ & \\
\hline
\end{tabular}




\begin{tabular}{|c|c|c|c|}
\hline $\begin{array}{l}3 \text { Matjan } \\
\text { (Diduga Primissima) }\end{array}$ & $42 / 171 / 2$ & $f 0,171 / 2$ & \\
\hline $\begin{array}{l}\text { Kroon Merah/Biroe } \\
\text { (Diduga Primissima) }\end{array}$ & $42 / 171 / 2$ & $f 0,20$ & \\
\hline $\begin{array}{l}\text { Ikan Tiga } \\
\text { (Prima) }\end{array}$ & $42 / 171 / 2$ & $f 0,20$ & Belanda \\
\hline $\begin{array}{l}\text { Ajam Mas } \\
\text { (Prima) }\end{array}$ & $42 / 171 / 2$ & $f 0,20$ & Belanda \\
\hline $\begin{array}{l}\text { Badjing } \\
\text { (Diduga Prima) }\end{array}$ & $42 / 171 / 2$ & $f 0,20$ & \\
\hline $\begin{array}{l}\text { Blue Bird } \\
\text { (Diduga Prima) }\end{array}$ & $40 / 161 / 2$ & $f 0,15$ & \\
\hline $\begin{array}{l}3 \text { Matjan } \\
\text { (Diduga Prima) }\end{array}$ & $40 / 161 / 2$ & $f 0,15$ & \\
\hline $\begin{array}{l}\text { Kroon Merah/Biroe } \\
\text { (Diduga Prima) }\end{array}$ & $40 / 161 / 2$ & $f 0,15$ & \\
\hline $\begin{array}{l}\text { Shell } \\
\text { (Diduga Prima atau Biru) }\end{array}$ & $40 / 161 / 2$ & $f 0,15$ & \\
\hline $\begin{array}{l}\text { Batik Perak } \\
\text { (Biru) }\end{array}$ & $40 / 161 / 2$ & $f 0,171 / 2$ & Belanda \\
\hline $\begin{array}{l}\text { Gouden Vogelkooi } \\
\text { (Diduga Biru) }\end{array}$ & $40 / 161 / 2$ & $f 0,171 / 2$ & \\
\hline $\begin{array}{l}\text { Sawah Mas }{ }^{1} \\
\text { (Prima/Biru) }\end{array}$ & $40 / 161 / 2$ & $f 0,17 \frac{1}{2}$ & \\
\hline $\begin{array}{l}\text { Bintang Woengoe }{ }^{2} \\
\text { (Medium/Biru) }\end{array}$ & $40 / 48$ & $f 0,571 / 2$ & \\
\hline $\begin{array}{l}\text { Pajong Biroe } \\
\text { (Biru) }\end{array}$ & $40 / 48$ & $f 0,571 / 2$ & Belanda \\
\hline $\begin{array}{l}\text { Merak } \\
\text { (Diduga Biru) }\end{array}$ & $40 / 45$ & $f 0,571 / 2$ & \\
\hline $\begin{array}{l}\text { Pajoeng Biroe } \\
\text { (Biru) }\end{array}$ & $41 / 161 / 2$ & $f 0,20$ & Belanda \\
\hline $\begin{array}{l}\text { Boerak Biroe } \\
\text { (Biru) }\end{array}$ & $40 / 161 / 2$ & $f 0,20$ & \\
\hline $\begin{array}{l}\text { Alie Merah } \\
\text { (Tidak diketahui) }\end{array}$ & $40 / 48$ & $f 0,40$ & \\
\hline
\end{tabular}

Diolah dari “Steun Aan de Batikindustrie” (1936), Hwat (1934) dan Susanto (1974)3

\footnotetext{
${ }^{1}$ Merek Sawah Mas dalam katalog kain Manex N.V. Oldenzal (1953) merupakan merek kain jenis prima yang memiliki ukuran 42/171/2. Namun kain dalam tabel ini berukuran berbeda dengan ukuran standar kain prima (lihat Susanto, 1974).

${ }^{2}$ ibid

${ }^{3}$ Susanto dalam Seni Kerajinan Batik Indonesia (1974) menyebutkan bahwa setiap kain mori memiliki standar ukuran. Mori primissima dari Belanda umumnya diperdagangkan dalam ukuran 42 inchi $x$ 17,5 yard per piece (blok). Sementara untuk mori prima dari Belanda berukuran 40 inchi $x \pm 16$ yard dan dari Jepang memiliki ukuran dengan primissima dari Belanda (42 inchi x 17,5 yard). Mori biru yang kualitasnya berada di bawah prima apabila dari Belanda memiliki ukuran variatif, yakni 40 inchi x 16 yard, 30 yard, 40 yard, 45 yard atau 48 yard. Mori biru dari Jepang hanya memiliki satu ukuran yakni 42 inchi x 48 yard. Jenis mori terakhir yakni mori blacu atau grey memiliki ukuran 30-43 inchi $x$ 48 yard.
} 
Pemerintah Hindia Belanda tidak tinggal diam menghadapi penetrasi ekspor yang dilakukan Jepang pada dekade 1930-an. Ditetapkan Crisisinvoerordonnantie atau peraturan krisis impor pada September 1933 yang membatasi impor kain bermotif dan kain katun putih (1934) dan kain grey pada 1935 (van Der Eng, 2013). Kebijakan contingentering atau sistem kuota untuk kain katun putih diterapkan pada 1 Maret 1934 ini berdampak pada keterbatasan kain katun putih (Wirodihardjo, 1954). Namun pada 2 Maret 1936, pemerintah memutuskan pemberian pengurangan harga kain putih agar industri batik dapat kembali berjalan (lihat tabel 1). Koperasi batik yang dibentuk di Setono dan Pekajangan pada tahun 1939 merupakan salah satu jalan yang dipilih untuk menyelesaikan permasalahan ini. Aman Jahri, Mastur, Mufti, Ridwan, dan Zen Muhammad adalah para pengusaha yang turut mendukung berdirinya kedua koperasi ini (Pratiwi, 2013). Gerakan koperasi ini memiliki 3 tujuan yang bertahap yakni membeli kain katun cambrics langsung dari importir, mengimpor sendiri kain dari luar negeri dan terakhir mendirikan serta memiliki pabrik kain sendiri (Wirodihardjo, 1954).

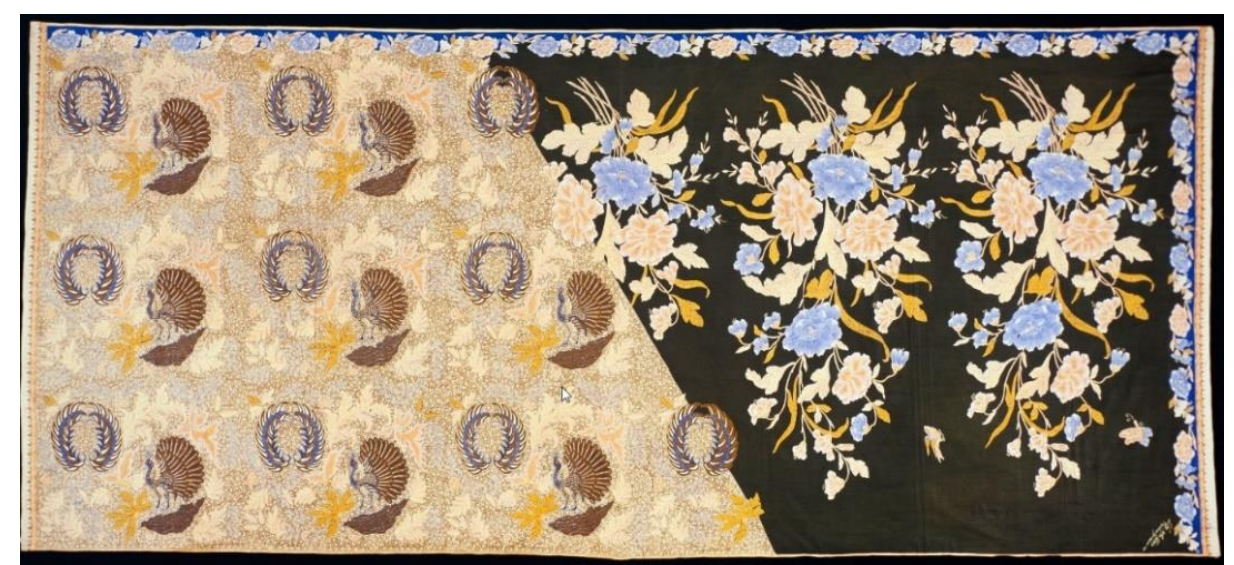

Gambar 5. Kain panjang pagi sore bukétan dan cuiri merak ati, asal Kedungwuni, Pekalongan sekitar tahun 1930 oleh Oey Soe Tjoen

Kain berukuran $240 \times 180 \mathrm{~cm}$ (Wereld Museum Rotterdam)

Penetrasi Jepang pada dekade 1930-an ini menyebabkan perubahan tren batik di Pekalongan. Gaya pagi sore menjadi populer karena harga kain putih yang melambung. Ciri khas dari kain dengan gaya pagi sore dekade 1930-an adalah dari segi pemilihan motif dan warna. Motif yang cukup sering digunakan di Pekalongan adalah bukétan (Ilyas, 2018) seperti pada foto 2.2. Hal ini lazim mengingat motif bukétan masih menjadi pilihan terutama bagi kalangan peranakan Tionghoa sejak dekade 1920-an (Elliot, 2004). 


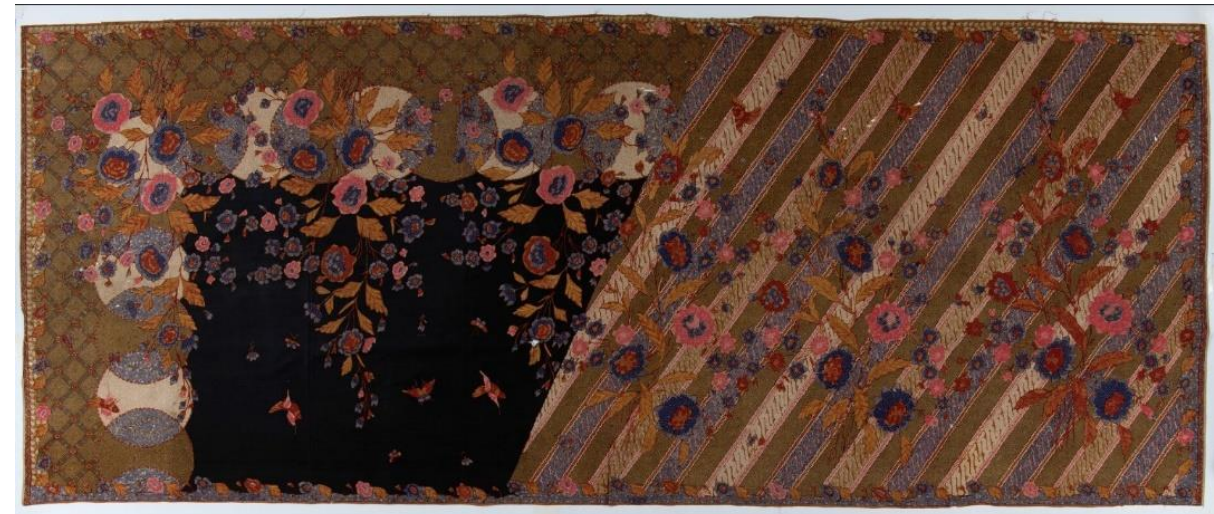

Gambar 6. Batik pagi sore pengaruh Jepang, asal Pekalongan tahun 1941

Kain berukuran 249x 105cm

(Wereld Museum Rotterdam)

Dampak yang dapat dijumpai secara langsung adalah ragam hias Jepang dalam batik Pekalongan. Ragam hias yang lazim dijumpai gaya batik Jawa Hokokai jejaknya dapat ditemukan sebelum organisasi tersebut ada. Semisal foto 4 tampak perpaduan antara motif khas Vorstenlanden atau keraton yakni lereng dan bukét bunga aster. Warna bernuansa kuning walau belum secerah gaya Jawa Hokokai juga mulai terlihat. Saat Jepang mulai menguasai Karesidenan Pekalongan pada 1942, krisis kain kembali terjadi. Lucas (2020) menyebutkan bahwa terjadi pembagian stok kain di pabrik-pabrik tekstil, salah satunya The Java Textile Factory. Sebagian besar jatah kain diberikan kepada militer Jepang dan sisanya dibagikan untuk rakyat. Hal ini menyebabkan rakyat mendapatkan jatah bahan sandang yang lebih terbatas. Situasi diperburuk dengan kelakuan pejabat lokal yang menimbun kain untuk dirinya sendiri.

Periode pendudukan militer Jepang menjadi periode sulit dalam industri batik di Pekalongan. Pengusaha-pengusaha batik Indo-Eropa kecuali Eliza van Zuylen dimasukkan kamp interniran (Veldhuisen, 2007). Hal ini secara otomatis menyebabkan tenaga pembatik kehilangan pekerjaannya. Sebagai akibatnya, para tenaga pembatik yang masih bertahan melakukan padat karya di perusahaan batik yang tersisa (Ishwara, 2011). Kwee Nettie dalam Widjaja (2020) menyebutkan cara bertahan dari krisis ini adalah dengan menukar kain batik siap jual dengan kain mori polos. Nilai barter satu kain batik siap jual setara dengan dua atau tiga kain mori polos, tergantung nilai kain batik yang sudah jadi. 


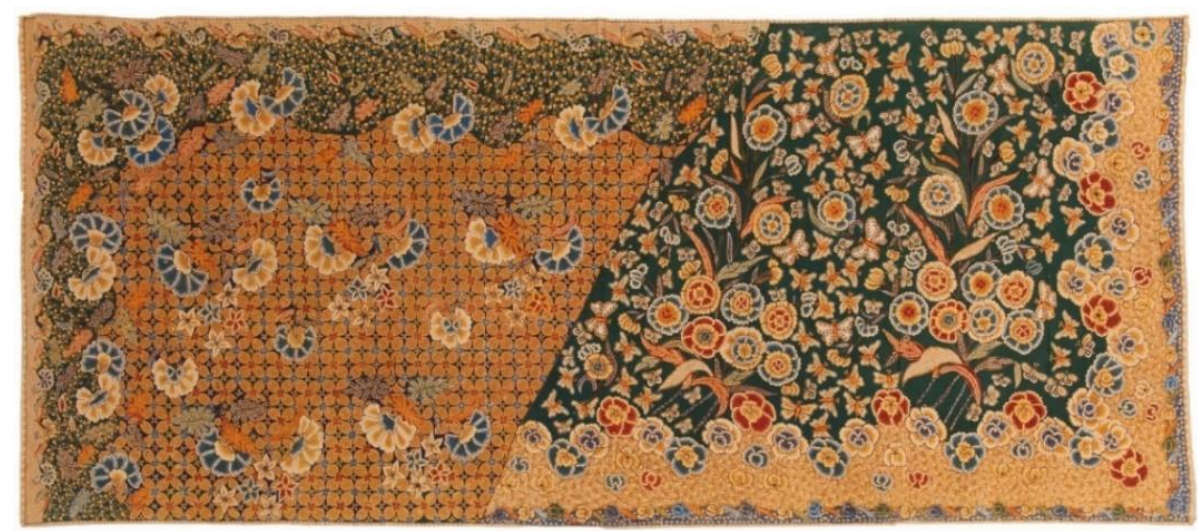

\section{Gambar 7. Batik Jawa Hokokai, asal Pekalongan tahun 1945 Kain berukuran $248 \times 107 \mathrm{~cm}$ (Wereld Museum Rotterdam)}

Efek dari padat karya serta pengaruh selera pasar yang berfokus pada orang-orang Jepang menyebabkan corak-corak khas Jepang dimasukkan dalam batik yang dikembangkan. Oleh karenanya, gaya batik Jawa Hokokai mulai berkembang. Gaya ini merupakan perkembangan dari gaya pagi sore (Purnomo, 2018). Semisal pada foto 5 , terdapat isen pola dan isen latar yang nampak rumit. Motif batik keraton yakni kawung nampak dipadukan dengan bunga sakura pada kain ini. Hal ini merupakan ciri gaya batik Jawa Hokokai. Selain itu pemilihan warna seperti kuning, turqoise, lembayung, merah dan merah muda juga menjadi tata warna yang khas (Doellah, 2002).



\section{Gambar 8. Batik Jawa Baru, asal Pekalongan tahun tidak diketahui}

(Doellah, 2002)

Penggunaan tata warna yang cerah didapatkan karena sebagian besar batik bergaya Jawa Hokokai diproduksi menggunakan pewarna sintetis. Pewarna yang paling memungkinkan digunakan adalah Auramine atau Napthol. Hal ini dapat dirunut dari resep warna Jawa Baru (lihat foto 6) sebagai pengembangan dari gaya Jawa Hokokai pasca 
kemerdekaan. Penggunaan warna kuning masih dapat ditemukan dalam Recept-batik Djilid Ka III (Hwat, 1950). Penamaan gaya batik Jawa Hokokai sebenarnya problematik. Organisasi Jawa Hokokai sendiri baru berdiri pada 8 Januari 1944 (Post, 2010). Sebelum Jawa Hokokai terdapat organisasi Poesat Tenaga Rakjat atau Poetera. Organisasi yang berdiri pada 1 Maret 1942 dinilai lebih menguntungkan orang Indonesia daripada Jepang sendiri. Penyebabnya adalah tokoh-tokohnya justru memanfaatkan Poetera sebagai alat propaganda untuk meningkatkan militansi rakyat (Legawa, 2009). Salah satunya adalah Kromolawi, tokoh Poetera yang kelak menjadi Kepala Seksi Perdagangan Jawa Hokokai Pekalongan (Asa, 2006). Pemasaran batik diberikan wadah dalam Jūmin Keizai Kyoku atau Biro Ekonomi Rakyat. Biro ini berdiri pada 25 Juli 1944 di bawah Departemen Perindustrian (Post, 2010). Asa (2006) menyebutkan bahwa para pengusaha batik di Pekalongan baik dari bumiputera, Arab, dan Tionghoa memasarkan ke badan ekonomi bentukan Jepang. Badan ini dapat ditafsirkan sebagai Jümin Keizai Kyoku. Pemasaran yang ditentukan pemerintah pendudukan Jepang menjadikan selera pasar batik Pekalongan bergantung penuh pada orang-orang Jepang.

\section{Kesimpulan}

Industri batik di Pekalongan pada tahun 1920 berada di masa keemasannya. Namun hal ini tidak berlangsung lama dengan adanya Depresi Ekonomi pada 1929 serta penetrasi ekonomi Jepang melalui ekspor kain ke Hindia Belanda yang begitu masif. Tren batik di Pekalongan sendiri mengalami perubahan sejak awal abad ke-20. Hal ini disebabkan oleh faktor tren tata warna dan motif yang berkiblat ke pesisir utara Jawa. Pewarnaan yang semula berdasarkan flora khas daerah dikembangkan menjadi lintas daerah dan pada akhirnya beralih pada pewarnaan sintetis utamanya pada saat malaise tahun 1929. Dominasi Jepang atas pasar impor kain di Hindia Belanda melalui jejaring usaha memengaruhi tata warna dan motif batik di Pekalongan secara perlahan. Ketika masa pendudukan Jepang pada 1942-1945, selera pasar bergantung penuh pada orang-orang Jepang akibat kain batik sebagai alat tukar untuk kain putih serta perdagangan batik yang dikontrol penuh oleh pemerintah pendudukan Jepang melalui wadah Jümin Keizai Kyoku.

Penamaan batik Jawa Hokokai yang problematik perlu mendapatkan alternatif. Hal ini diperlukan agar miskonsepsi bahwa batik Pekalongan pada masa Jepang dipukul rata berawal dari organisasi Jawa Hokokai tidak berlanjut. Selain itu penelitian mengenai kontinuitas unsur Jepang dalam batik pasca-pendudukan Jepang juga perlu dikaji lebih lanjut.

\section{Daftar Pustaka}

Angelino, P. de K. (1930). Batikrapport van P. de Kat Angelino.

Asa, K. (2006). Batik Pekalongan dalam Lintasan Sejarah. Paguyuban Pecinta Batik Pekalongan. 
Bruggen, M. P. van, Hering, B. ., Wassing, R. ., Voskuil, R. P. G. ., \& Heshusius, C. . (1998). Djokja en Solo: Beeld van de Vorstensteden. Asia Maior.

Chattopadhyay, D. P. (2011). Azoic dyeing. In Handbook of Textile and Industrial Dyeing: Principles, Processes and Types of Dyes (Vol. 1, pp. 604-626). Elsevier Inc. https://doi.org/10.1533/9780857093974.2.604

Doellah, S. (2002). Batik: Pengaruh Zaman dan Lingkungan. Danar Hadi.

Elliot, I. M. (2004). Batik Fabled Cloth of Java (1st ed.). Periplus.

Fatiyah. (2016). Sejarah Keturunan Arab di Yogyakarta Abad XX. Magnum Pustaka Utama.

Furnivall, J. S. (2010). Netherlands India: A Study of Plural Economy (2nd ed.). Cambridge University Press.

Gondowinoto, I., \& Merta, D. (2019). Batika: Jejak Batik Keluarga Gan Tjioe Liam (2nd ed.). Global Pustaka Utama.

Graaf, H. J. de. (1986). Puncak Kekuasaan Mataram : Politik Ekspansi Sultan Agung. Grafitipers. Hadisoemarto, S., \& Soetopo, S. (1953). Penuntun Batik. Balai Penjelidikan Batik Jogjakarta.

Haryono, A. (1990). Dari Keraton ke Pasar: Industri Pribumi di Daerah Yogyakarta 18301930-an. Humaniora, 21(1), 97-108.

Hayati, C. (2015). Batik sebagai Media Integrasi Sosial, Ekonomi, Budaya Masyarakat Kota Pekalongan. Jejak Nusantara, 03(2), 111-121.

Hwat, L. (1934). Recept-batik: Dari Kain Poetih sampe Djadi Batik jang Bagoes Djilid Kesatoe. Fortuna.

Hwat, L. (1950). Recept-batik: Djilid Ka III. Fortuna.

Ilyas, A. (2018). Industri Batik Pekalongan: Pergulatan Tanpa Akhir. Dinas Kearsipan dan Perpustakaan Kota Pekalongan.

Indisch Verslag. (1936). Gedrukt ter Algemeene Landsdrukkerij.

Ishwara, H. (2011). Batik Pesisir Pusaka Indonesia Koleksi Hartono Sumarsono. Kepustakaan Populer Gramedia.

Istari, T. M. R. (2016). Ragam Hias Non-Cerita Pada Relief Candi Untuk Perkembangan Motif Batik Kontemporer. Naditira Widya, 6(1), 64. https://doi.org/10.24832/nw.v6i1.84

Japan en Batik. (1934, July 9). Bataviaasch Nieuwsblad.

Jasper, J. E. (1923). De Eerste Pekalongansche Jaarmarkt-Tentoonstelling van Inlandsche Nijverheid en Kunstneijverheid in 1923. G. Kolff \& Co.

Jasper, J. E., \& Pirngadie, M. (1916). Inlandsche Kunstnijverheid in Nederlandsch Indie III : De Batikkunst. Mouton \& Co.

Kramers, J. J., \& van Wely, F. P. H. P. (1960). Kramers' Engels Woordenboek : Engels-Nederlands en Nederland-Engels (26th ed.). Van Goor. http://lib.ugent.be/catalog/rug01:001802352

Kuntowijoyo. (2013). Pengantar Ilmu Sejarah. Tiara Wacana.

Legawa, I. W. (2009). Gerakan Politik pada Masa Penjajahan Jepang. Sejarah Dan Budaya, 2(2), 31-47. $\quad$ http://training.um.ac.id/ojs/index.php/sejarah-danbudaya/article/download/4707/1095

Lucas, A. (2020). Peristiwa Tiga Daerah (2nd ed.). Media Pressindo.

Malagina, A. (2018, February). Adiwastra Tiga Negeri. National Geographic Indonesia.

Manex N.V. Oldenzal. (1953). White Cambrics Twente Holland. Manex N.V.

Mulyawan, B. (2017). Batik Pekalongan dari Masa ke Masa. Bank Central Asia.

Murayama, Y. (1998). Pola Penetrasi Ekonomi Jepang ke Hindia Timur Belanda Sebelum Perang. In S. Shiraishi \& T. Shiraishi (Eds.), Orang Jepang di Koloni Asia Tenggara (pp. 138-177). Yayasan Obor Indonesia.

Nawiyanto. (2010). Matahari Terbit dan Tirai Bambu: Persaingan Dagang Jepang-Cina. Penerbit Ombak.

Nurhayati, F. (2018). Batik Pekalongan pada Masa Kolonial (1830-1945). Universitas Muhammadiyah Purwokerto.

Post, P. (2009). Indonesianisasi and Japanization: The Japanese and The Shifting Fortunes of 
Pribumi Enterpreneurship. In J. Lindbland \& P. Post (Eds.), Indonesian Economic

Decolonization in Regional and International Perspective (pp. 61-86). KITLV Press.

Post, P. (2010). The Encyclopedia of Indonesia in the Pacific War. Brill.

Pratiwi, E. (2013). Perkembangan Batik di Pekalongan Tahun 1950-1970. Universitas Negeri Semarang.

Purnomo, M. A. J. (2018). The Existence of Batik Esuk-Sore Pekalongan Style. 41(2017), 24-31.

https://doi.org/10.2991/bcm-17.2018.5

Raffles, T. (1830). History of Java (2nd ed.). John Murray.

Rizali, N. (2018). Elements of Design in Batik Tiga Negeri, Lasem. 3rd International Conference on Education, Sports, Arts and Management Engineering (ICESAME 2018), 103-105. https://doi.org/https://doi.org/10.2991/amca-18.2018.29

Rouffaer, G. . (1904). De Voornamste Industrieen der Inlandsche Bevolking van Java en Madoera. Martinus Nijhoff.

Shiraishi, S., \& Shiraishi, T. (1998). Orang Jepang di Koloni Asia Tenggara: Sebuah Tinjauan. In S. Shiraishi \& T. Shiraishi (Eds.), Orang Jepang di Koloni Asia Tenggara. Yayasan Obor Indonesia.

Steun aan de Batikindustrie. (1936, March 2). Bataviaasch Nieuwsblaad.

Susanto, S. K. S. (1974). Seni Kerajinan Batik Indonesia. Balai Besar Kerajinan Batik.

Sutriyanto, \& Kristanti, V. (2014). Kajian Visual Batik Hokokai Pekalongan Motif Lereng, Bunga Dan Kupu. Ornamen, Jurnal Kriya Seni ISI Surakarta, 11(2), 2-3.

Valen, L. Van. (2016). De strijd om de textielmarkt in Nederlands-Indië. Universiteit Leiden.

VAN DER ENG, P. (2013). Why Didn't Colonial Indonesia Have a Competitive Cotton Textile Industry? Modern Asian Studies, 47(3), 1019-1054. https://doi.org/10.1017/S0026749X12000765

Veldhuisen, H. (2007). Batik Belanda 1840-1940: Pengaruh Belanda pada Batik dari Jawa Sejarah dan Kisah-kisah di Sekitarnya. Gaya Favorit Press.

Widjaja, W. (2020). Oey Soe Tjoen: Merajut Asa dalam Sejuta Impian (B. Mulyawan \& S. Indriyani (Eds.)). Lembaga Kajian Batik.

Wie, T. K. (2013). The Indonesian Economy During The Japanese Occupation. Masyarakat Indonesia, 39(2), 327-340.

Wirodihardjo, S. (1954). Ko-operasi dan Masalah Batik. Penerbit Gabungan Ko-operasi Batik Indonesia. 